\title{
Multifunctional Amyloids in the Biology of Gram-Positive Bacteria
}

\author{
Ana Álvarez-Mena ${ }^{\dagger}$, Jesús Cámara-Almirón ${ }^{\dagger}$, Antonio de Vicente (D) and Diego Romero *(D) \\ Instituto de Hortofruticultura Subtropical y Mediterránea “La Mayora"—Departamento de Microbiología, \\ Universidad de Málaga, Bulevar Louis Pasteur, 31 (Campus Universitario de Teatinos), 29071 Malaga, Spain; \\ alvarezmena@uma.es (A.Á.-M.); jesus_camara@uma.es (J.C.-A.); adevicente@uma.es (A.d.V.) \\ * Correspondence: diego_romero@uma.es; Tel.: +34-952131624 \\ + These authors contributed equally to this work.
}

Received: 26 November 2020; Accepted: 14 December 2020; Published: 17 December 2020

check for updates

\begin{abstract}
Since they were discovered, amyloids have proven to be versatile proteins able to participate in a variety of cellular functions across all kingdoms of life. This multitask trait seems to reside in their ability to coexist as monomers, aggregates or fibrillar entities, with morphological and biochemical peculiarities. It is precisely this common molecular behaviour that allows amyloids to cross react with one another, triggering heterologous aggregation. In bacteria, many of these functional amyloids are devoted to the assembly of biofilms by organizing the matrix scaffold that keeps cells together. However, consistent with their notion of multifunctional proteins, functional amyloids participate in other biological roles within the same organisms, and emerging unprecedented functions are being discovered. In this review, we focus on functional amyloids reported in gram-positive bacteria, which are diverse in their assembly mechanisms and remarkably specific in their biological functions that they perform. Finally, we consider cross-seeding between functional amyloids as an emerging theme in interspecies interactions that contributes to the diversification of bacterial biology.
\end{abstract}

Keywords: functional amyloids; gram-postive bacteria; Bacillus; microbial ecology; biofilm; pathogenesis

\section{Introduction}

The term "amyloid" has been historically associated with misfolded proteins with a tendency to accumulate in neural tissue, causing a broad range of neurological disorders known as proteopathies or protein misfolding diseases, such as Alzheimer's disease or Parkinson's disease [1]. The histological manifestation of these pathological conditions is, indeed, the amyloid deposits that were first observed by pathologist Rudolph Virchow in 1854 [2]. These deposits resembled carbohydrate starches when stained with iodine compounds, which in Latin are called amylum and hence the term "amyloid". During the 1960s and 1970s it was demonstrated that some of these disorders can be experimentally transmitted to animals and, in some conditions, to humans. Since then, the study of the transmission of these protein misfolded diseases has been key to understand the properties of amyloid proteins. Such is the case of Alzheimer's disease [3] in which the use of contaminated surgical instruments and blood products in patients with no prior history of neurological disorders led to changes in the brain that resemble those found in patients with Alzheimer's disease, due to the presence of $A \beta$ seeds adhered to metal surfaces that can resist the inactivation by formaldehyde or other physicochemical treatments [4].

Currently, amyloids are not simply misfolded proteins; they are widely distributed from prokaryotic to eukaryotic and are implicated in a broad range of biological processes, such as protection, interaction with abiotic and biotic surfaces and detoxification [5-13]. For these reasons, 
some amyloid proteins have been termed "functional amyloids", which refers to their ability to perform useful biological functions for the organism.

One of the defining features of amyloid proteins is the differences in their amino acid sequence and, despite this difference, the strongly conserved quaternary structure of cross- $\beta$ strands [14]. This well-ordered architecture is formed by oligomers that adopt a $\beta$-sheet structure noncovalently bound by hydrogen bonds. These proteins have the ability to self-assemble in a nucleation-dependent process from monomers to oligomers that ultimately lead to fibres with a diameter of a few nanometres and with a length from tens of nanometres to several micrometres. This $\beta$-sheet enrichment confers tinctorial properties of amyloid proteins, and can be stained by dyes such as Congo red or thioflavin $\mathrm{T}(\mathrm{ThT})[15,16]$. Moreover, the canonical, ordered, cross- $\beta$ architecture can be identified by X-ray diffraction. Nonetheless, detection by nuclear magnetic resonance (NMR), Fourier transform infrared spectroscopy (FTIR) or even paramagnetic resonance profiles are other alternatives to study the structure of amyloid proteins [17].

An interesting trait shown by some amyloids is their ability to interact with one another in a process known as cross-seeding, which has attracted interest in recent years due to the interaction of different amyloids between different species. In fact, it has been shown that the cross-seeding between bacterial and human amyloids can lead to an enhancement of amyloidosis related to neurodegenerative disorders. Further studies are needed to determine, in detail, the effects of bacterial amyloids in human deposits and in the host immune response [18].

The conserved cross- $\beta$ structure gives amyloid proteins characteristic biophysical properties, such as insolubility and high resistance to different physicochemical aggressions, such as proteolysis, detergent treatments, and chemical or thermal denaturation [19]. Due to the high stability and robustness exhibited by this family of proteins, amyloids are frequently compared to steel in terms of strength $[20,21]$.

In prokaryotes, functional amyloids have been identified in Proteobacteria, Bacteroidetes, Chloroflexi, Actinobacteria, and Firmicutes [22-24]. The most studied and first identified bacterial amyloid was curli from Escherichia coli, which is implicated in a variety of physiological functions $[8,25]$ and that has been later identified in strains of Salmonella, Citrobacter and Enterobacter [26]. Since then, many amyloids have been reported as versatile proteins that are mainly involved in not only biofilm formation and adhesion to surfaces but also cytotoxicity, virulence, plasmid replication and reproduction [6-9,11,27-33]. Bacterial biofilms are communities of a single or multiple species of microorganisms attached to a surface formed in response to a myriad of signals that trigger a process of cellular differentiation and secretion of a multifunctional extracellular matrix (ECM). Protecting cells from environmental stress (antimicrobials, host defences, UV radiation, desiccation, mechanical stress, and phage predation), providing stability to the biofilm architecture and regulating the flow of nutrients and signalling molecules are among the essential functions covered by the ECM [34-36]. The ECM is mainly composed of exopolysaccharides, extracellular DNA, lipids, and proteins, but the proportions of these biomolecules vary depending on the species. Due to their chemical features, amyloids are members of the ECM, participate in adhesion to biotic or abiotic surfaces, provide robustness to biofilms, and compose a structural scaffold that serves to build the microbial community $[10,11,37,38]$. However, the unique features of amyloid proteins have captivated the interest of different disciplines beyond pathology and bacteriology, such as nanomaterial engineering and other biotechnological applications [39,40]. Emerging pharmacological studies are focused on the inhibition of amyloidogenesis as an antibacterial or antivirulence therapy, although some compounds promote the development of neurodegenerative diseases in humans, so dedicated attention should be maintained [41].

In this review article, we present the current knowledge and latest findings of different bacterial amyloid systems, with particular emphasis on gram-positive bacteria, their contribution to bacterial multicellularity and microbe-host interactions, and how the process of cross-seeding between different bacterial amyloids can diversify their functionality in microbial biology. 


\section{The Hydrophobic Layers of Streptomyces coelicolor: Chaplins and Rodlins}

One of the first functional amyloids reported in gram-positive bacteria was in Streptomyces coelicolor, a soil-dwelling bacterium with a lifecycle similar to that of filamentous fungi, in which a submerged mycelium emerges and aerial hyphae are developed to finally septate into chains of spores [28,42]. After being dispersed by insects or wind, the spores can germinate to form a new vegetative mycelium. The surface of aerial hyphae is extremely hydrophobic compared to the submerged hyphae, and three functional amyloids are involved in the formation of these structures: chaplins, rodlins and SapB [43,44].

Chaplins (coelicolor hydrophobic aerial proteins) are a family composed of eight secreted proteins (ChpA-H), but only the $\operatorname{ch} p C, \operatorname{ch} p E$ and $\operatorname{ch} p H$ chaplin genes are conserved in all Streptomyces species [45-47]. Except for $\operatorname{chpB}$, all chaplin genes are encoded in the core region of the lineal chromosome of S. coelicolor [42]. Strains with the deletion of individual or pairs of chaplin genes do not show phenotypic changes, so a possible redundancy in function could exist between these proteins [28]. In fact, a "minimal chaplin strain", encoding only the three conserved genes mentioned above, exhibits a wild-type-like phenotype with a robust aerial mycelium [48]. Furthermore, it is known by transcriptomic analysis that there is a temporal differentiation in the expression pattern of the different chaplin genes, in which $\operatorname{ch} p C, \operatorname{chpE}$ and $\operatorname{ch} p H$ are expressed in an early stage of aerial hyphal formation, and $\operatorname{ch} E$ and $\operatorname{ch} p H$ are induced during the later stages of the developmental cycle [28,42]. Streptomycetes are able to adhere to different surfaces, with the ability to grow as an invasive form or to establish an infection in the case of pathogenic strains. Fimbrial structures are implicated in attachment, and in Streptomyces coelicolor protrusions emerging along the surface of the hyphae are chaplin-dependent, suggesting that fimbriae might be composed of or related to these functional amyloids [49].

All chaplins possess a conserved region called the chaplin domain, are highly hydrophobic and contain three conserved GN motifs. Additionally, each amino acid sequence possesses two cysteine residues (except for ChpE) that form intramolecular disulfide bonds that, in the case of $\mathrm{ChpH}$, are essential for the development of aerial hyphae and for the building of the rodlet ultrastructure [48]. The chaplin family is divided into two groups, depending on the number of these chaplin domains: (i) the long chaplins (ChpA-C), which have two chaplin domains separated by 35 amino acids and a C-terminal signal recognized by a sortase for covalent attachment to the cell wall; and (ii) the short chaplins (ChpD-H), which contain a single chaplin domain [28,50,51]. A model for chaplin assembly proposed by Elliot, M.A. and colleagues suggested that long chaplins have a role as a scaffold for the proper polymerization and attachment of short chaplins to the cell wall, thereby forming, in conjunction, a hydrophobic surface that provides protection from and reduction in the surface tension during the development of aerial hyphae [28]. Given the amyloid nature of chaplins, these proteins are enriched in $\beta$-sheet secondary structures and are highly insoluble and can be stained with the amyloid-specific dyes Congo red and ThT $[42,49]$. ChpH is one of the most studied chaplin proteins due to its presence in all Streptomyces species. In the $\mathrm{ChpH}$ sequence, there are two regions that are described as amyloidogenic domains and that are responsible for the assembly process in other amyloids [52,53]. In vivo studies have shown that both domains are indispensable for the development of aerial hyphae, but only the region located near the C-terminal end participates in the formation of the rodlet surface [54].

Rodlins (RdlA and RdlB) play a similar role as fungal hydrophobins and are able to polymerize into a structure that resembles a basketwork of paired rodlets (also known as the rodlet layer) on the surface of aerial hyphae and spores. These proteins are known to be involved in the attachment of hyphae to hydrophobic surfaces [55]. This ordered structure is larger than the chaplin fibres, which are organized into pairs along the surface by the activity of RdlA and RdlB $[55,56]$. Studies regarding the surfactant activity of these proteins, however, demonstrated that rodlins are less effective in lowering the surface tension than chaplins [57]. Rodlins are poorly biochemically characterized, given the impossibility of separating them using the established trifluoroacetic acid extraction procedure [56]. Despite the similarity between the two Rdl proteins ( $>90 \%)$, each one has a unique functional role, and therefore, both are essential in the assembly process [57]. Indeed, both proteins differ by only a few 
amino acids located in their N-terminal domain, which is the reason for the lower net charge and the higher hydrophobicity of RdlB than RdlA. RdlB presents a higher tendency to form amyloid-like fibres in vitro; however, RdlA barely forms a few irregular amorphous aggregates [57].

As mentioned before, chaplin and rodlin fibres are located on the surface of aerial hyphae and spores, assemble into a paired-rod ultrastructure called the rodlet layer $[42,56]$, provide protection against desiccation and provide support as scaffolds due to the high level of hydrophobicity exhibited by these amyloid proteins. The mechanism by which chaplins and rodlins cooperate together is crucial to understanding how the rodlet layer is formed.

Finally, SapB (spore-associated protein B) is described as a "lantibiotic-like" molecule, although antibiotic activity has not been reported for this molecule [58], and acts as a surfactant under high osmolarity [59]. Under these environmental conditions, when releasing the hyphae into the air is difficult due to a lower turgor pressure, SapB is hypothesized to work cooperatively with chaplins in reducing their assembly at the air-liquid interface and therefore prevents the formation of a rigid membrane that increases the time of high surface activity $[53,60]$. Peptides that are homologous to SapB have been identified in other Streptomyces species $[44,61,62]$.

\section{Multifunctional Amyloids in Staphylococci: Phenol Soluble Modulins (PSMs), BapC, and SuhB}

The opportunistic pathogen Staphylococcus aureus is a resident bacterium of the skin or mucosa of mammals, producing, in some cases, severe infections and septicemia, and Staphylococcus epidermidis, which is often found in different medical devices or indwelling catheters, is known for its tendency to form biofilms that are resistant to the host immune response, chemotherapy and disinfectants [63]. In 1999, phenol soluble modulin (PSM) peptides were described by Seymour Klebanoff as a proinflammatory "complex" in the phenol phase during hot phenol extraction [64]. To date, PSMs, which are peptides with notable surfactant properties, have been extensively studied in these two bacterial species $[65,66]$. It is known that each staphylococcal species possesses a specific cluster of PSMs, and some of them, but not all, share sequence homology to some extent. This difference precisely could reflect the diversity in the lifestyles of S. aureus and S. epidermidis [64,67-70]. Indeed, it has been demonstrated that the expression of PSMs is higher in pathogenic methicillin-resistant strains of S. aureus than in strains that have a non-pathogenic lifestyle $[69,71]$, but further studies are needed to better establish a possible correlation between PSM peptides and virulence [72].

PSM peptides can be classified depending on their length. The smallest peptides are $\alpha$-type PSM $\alpha 1-4$ in S. aureus, PSM $\alpha, \mathrm{PSM} \delta$ and PSM $\varepsilon$ in S. epidermidis and $\delta$-toxin in both S. aureus and S. epidermidis. This group of peptides is characteristically composed of 20-25 amino acids with either a positive or neutral net charge. The longer peptides, which are 44 amino acids in length, are PSM $\beta 1$ and PSM $\beta 2$ from S. aureus and S. epidermidis, and they have a negative net charge $[64,67,70]$. In S. aureus, the genes that encode the PSM peptides are located in three different parts of the core genome: four peptides in the $\alpha$-operon (psm $\alpha 1-4)$, two peptides in the $\beta$-operon (psm $\beta 1-2)$ and one peptide in the $\delta$-toxin locus that is encoded in the region of the regulatory RNA RNAIII $[64,69,73]$. Similar to other staphylococcal exotoxins, the global regulator Agr (accessory gene regulator) enhances PSM expression and production at a high cell density, thereby promoting virulence $[69,74]$. PSM peptides have antimicrobial activity against niche bacteria [72,75], and they are also implicated in having pathogenicity, hindering the immune response and lysing host cells [76,77]. Furthermore, these surfactant-like molecules act as functional amyloids in the development of biofilms, giving physical support and stability to the scaffold [11,78]. Despite its sequence similarity, not all PSM peptides form ordered amyloid structures, and the PSM $\alpha 1$ and PSM $\alpha 4$ peptides are described to be the main contributors to fibrillar function, showing a high tendency to self-assembly into cross- $\beta$ fibres $[11,79,80]$, conferring essential stability to biofilms.

The most studied PSM peptide is the PSM $\alpha 3$ peptide, which exhibits the highest cytotoxic and lytic behaviours and contributes to all functions described for PSMs, from biofilm formation to immune activation $[66,76,81]$. This peptide maintains an $\alpha$-helical conformation in solution and in elongated 
fibres [82], which has been confirmed by X-ray diffraction analysis. PSM $\alpha 3$ was the first functional amyloid whose structure in the fibrillar form was studied at atomic resolution, showing that the $\alpha$-helices were perpendicular to the fibril axis and stack into sheets that run parallel to the fibril axis. The differences in the secondary and quaternary structures between PSM $\alpha 1$ and PSM $\alpha 4$ fibres, which fold into a canonical cross- $\beta$ structure, and the PSM $\alpha 3$ fibres, suggest a functional specificity.

As mentioned before, some PSMs are able to lyse a wide range of cell types, such as bone cells, monocytes and erythrocytes, by a mechanism that implies the perturbation of the target membrane in a receptor-independent manner [69,76,83-85]. Within the PSM group, the $\alpha$-type exhibits a greater cytolytic activity than the $\beta$-type. In S. aureus and S. epidermidis, PSM $\alpha 3$ and PSM $\delta$, respectively, are the most cytolytic PSM peptides, displaying cytotoxicity in the micromolar range. The antimicrobial peptides of $S$. aureus, such as the $\beta$-toxin or PVL, intensify the cytotoxicity of PSMs, suggesting a synergy between functional amyloids and other molecules [86,87]. PSM $\alpha 3$ is a virulence factor of S. aureus that is toxic to T-cells or human embryonic kidney 293 (HEK293) cells [82] but is ineffective against Bacillus subtilis, Pseudomonas aeruginosa, Micrococcus luteus or Streptococcus pyrogenes bacterial cells [78], indicating a significant degree of specificity. A modified peptide of PSM $\alpha 3$ was designed, in which the phenylalanine located at position 3 was replaced by an alanine. This version of PSM $\alpha 3$ was unable to self-assemble into fibres and was conceived with the aim of elucidating the role of the fibrils in the biological activity and virulence of PSM $\alpha 3$. Surprisingly, this modified peptide exhibited a gain of function, becoming lethal to B. subtilis cells but not to P. aeruginosa [78]. A study performed by simulating mammalian and bacterial membranes showed that PSM $\alpha 3$ interacts differently with the lipid bilayer depending on the lipid composition, which might provide an additional explanation for the differential cytotoxic behaviour of this peptide [88]. The role of PSM $\alpha 3$ fibrils is not completely understood, but recent work suggests that the positive charges and the cross- $\alpha$ structure are involved in its cytotoxicity, which provokes membrane disruption $[69,82]$.

Apart from PSM peptides, another functional amyloid called Bap (biofilm-associated protein) is also present in the staphylococcal biofilm matrix, where it functions as a surface adhesin. Bap was first identified in bovine mastitis caused by the S. aureus strain V329 [89] and is absent in human isolates; therefore, it is considered a host-specific pathogenic factor. Bap is a high molecular weight protein (2276 amino acids in length), is located on the bacterial surface, and has multiple domains along its sequence [90]. Bap is implicated in the initial adhesion to abiotic surfaces, intercellular adhesion and bacteria-host interactions, but the exact function of Bap in biofilm development is still unclear [91]. Moreover, this protein presents some similarities with the well-known curli of E. coli: cell surface location, multiple tandem repetitions in the carboxyl domain, coordinated synthesis with exopolysaccharide and biofilm formation by interaction with surfaces or cells [92]. Bap is expressed continuously during the bacterial growth curve [93], and the protein is processed by the cell to an insoluble amyloid-like aggregate that forms at a low $\mathrm{pH}$ and in a manner dependent on calcium concentration. At high calcium levels, metal-coordinated Bap is more stable, and the N-terminal domain does not assemble, inhibiting the aggregation between bacteria and, therefore, inhibiting biofilm formation, demonstrating the sensorial role of this protein in sensing the environmental conditions that affect biofilm formation.

Independent of Bap, a transposon mutagenesis study identified the protein SuhB as an essential factor for poly-N-acetylglucosamine-independent biofilm formation in S. aureus. Studies in E. coli [94], P. aeruginosa, Pseudomonas putida [95], Burkholderia cepacia [96], and others [97], have demonstrated the role of SuhB as a regulator of diverse biological functions, including protein secretion, expression of virulence factors, antibiotic resistance, exopolysaccharide production and biofilm development; however, the specific role in S. aureus biofilm formation remains unclear. Macroscopic fibres of SuhB have been observed by electron microscopy, and spectroscopic and structural analysis showed that the fibres formed by SuhB exhibited amyloid properties. Furthermore, this protein is able to adhere to the cell surface, indicating its possible role as a component of the biofilm matrix in S. aureus [98]. 


\section{Functional Amyloids in the Plaque: Streptococcus mutans Adhesin P1, Wall Associated Protein A (WapA) and Secreted Protein SMU_630}

Streptococcus mutans is capable of forming biofilms to survive and persist in dental plaque, causing human dental caries, also known as cavities. In addition, this gram-positive bacterium has been identified as a causative agent of infectious endocarditis. The tooth surface is covered by a salivary pellicle where $S$. mutans sticks to the salivary agglutinin glycoprotein (SAG) complex, which is mainly composed of the scavenger receptor gp340/PMBT1, host cell matrix proteins and other bacteria [99,100]. Binding to SAG is mediated by cell surface adhesin P1 (also named AgI/II, PAc, SpaP or antigen B), but the molecular mechanism of this interaction remains unclear. P1 is a multifunctional protein able to interact with the eukaryotic extracellular matrix proteins collagen and fibronectin, and it is also involved in the interactions between cells [101-105]. Adhesin P1 is a large protein (185 kDa) with multiple domains: A secretion signal peptide, an N-terminal region, three alanine (A)-rich repetitions, a region called variable (which differs between strains), three proline (P)-rich repetitions, a C-terminal region composed of three domains (C1-3) and, at the end, there is an LPxTG recognition motif for the covalent attachment of the protein to the cell wall by the action of the transpeptidase SrtA $[106,107]$. The protein folds in an unusual tertiary structure [108-110], in which the A and P regions form an $\alpha$-helix that entwines between them, forming a long narrow stalk. The variable part forms a $\beta$-sandwich between two sheets, and the C-terminal domain folds into similar structures. Therefore, the global tertiary structure is an extended stalk with a globular domain containing $\beta$-sheets. The C-terminal region of the protein can be found in two versions: as part of the full-length protein, in which it is anchored to the cell wall of $S$. mutans or as a single polypeptide that is covalently linked with the whole protein [111]. In electron microscopy studies of thin sections of $S$. mutans cells, adhesin is seen as a layer of fibres that emerge from the cell wall [112]. Upon heterologous expression, the P1 protein is able to fibrillate into fibres with amyloid properties [29], and it has been recently reported that the $\mathrm{C} 123$ domain of P1, also referred to as antigen II (AgII), contains the amyloid forming moiety [113].

The fact that biofilms of the S. mutans strain that is deficient in adhesin P1 still exhibits green birefringence under Congo red staining suggests the presence of additional proteins with an amyloid nature [29]. Indeed, two additional functional amyloids have been found in this microorganism: WapA [114] and the poorly characterized protein SMU-63c [113]. WapA is a polypeptide that occurs naturally as a result of the truncation of antigen A $[115,116]$, and it is similar to P1 when it is processed by the transpeptidase SrtA. It is involved in some functions, such as binding to collagen, affecting chain length and assembling biofilms $[115,117,118]$. To date, the crystal structure of WapA is not known. The ability of the C123 domain, which is present in the three functional amyloids, to assemble into fibres has been analysed [113], and shows that in the aggregated state, this domain forms a broad range of amyloid-like structures, from smaller amyloid fibrils (width of 7-12 nm and length of $15 \mathrm{~nm}$ to several micrometres) to higher structures (width of $90-150 \mathrm{~nm}$ ). Additionally, the amyloid inhibitors epigallocatechin-3-gallate or the benzoquinone derivative AA-861 inhibited the in vitro amyloid formation of the C123 domain and WapA and impaired biofilm development by a mechanism dependent on the three amyloid proteins. It is known that WapA and P1 act during the initial stages of biofilm formation; in contrast, SMU_63c is able to form fibres only under acidic conditions, suggesting the importance of the environmental $\mathrm{pH}$ in the different regulation of these three S. mutans proteins.

Some questions remain unanswered about the functions of each functional amyloid in S. mutans biology, and more research is needed to fully understand this system and the possible interactions between these functional amyloids.

\section{Functional Amyloids in Listeria monocytogenes}

This microorganism is a food-borne intracellular pathogen and the causative agent of listeriosis, an infectious disease that can cause severe symptoms such as meningitis or encephalitis and that, eventually, can lead to death [119]. Biofilms play an important role in the survival of this microorganism in the food processing industry, in which this microorganism is able to attach and proliferate over 
different surfaces [120]. Genome analysis of L. monocytogenes EGD revealed an ORF (Lmo0435, designated as BapL) that showed a high percentage of similarity with Bap of S. aureus or Esp from E. faecalis and that contributed to the attachment of L. monocytogenes EGD to different inert surfaces [121]. Interestingly, these two abovementioned proteins have been described as functional amyloids, showing all their canonical properties, and are important for the structuring of the extracellular matrix and multicellularity in response to different environmental conditions [93,122]. However, the amyloid nature of BapL remains to be demonstrated.

A paradigm example of the role of functional amyloids in pathogenic interactions with hosts is the toxin listeriolysin O (LLO). This protein is part of a family of toxins known as cholesterol-dependent cytolysins that are produced by different groups of bacterial pathogens, including Firmicutes, Actinobacteria and Proteobacteria, and that use cholesterol as a receptor [123]. LLO is required for the virulence of most of the strains of L. monocytogenes, and it is produced and secreted as a monomer that, upon contact with biological membranes, oligomerizes, forming a pre-pore structure of several units. After binding to the membrane, the $\alpha$-helical regions of the monomers are refolded into beta-hairpins that are inserted into the membrane, forming a beta-barrel pore [124]. Remarkably, LLO exhibits $\mathrm{pH}$-dependent behaviour that provides the pathogen with an escape strategy from eukaryotic phagolysosomes, ensuring the survival of the microorganism in the host cell and enabling infection. The optimal $\mathrm{pH}$ and temperature for the activity of LLO and pore formation is acidic $\mathrm{pH}$ (5.5) and $37^{\circ} \mathrm{C}$, which are conditions that resemble those found in human phagolysosomes. Under these environmental conditions, the protein is stable as soluble dimers become functional when they are in contact with the cell membrane, as this contact triggers their pore-forming activity [123]. However, under more alkaline conditions, such as at neutral pH found in the cell cytosol, LLO is inactive and forms amorphous aggregates that have many of the properties of amyloid proteins [125] (Figure 1). In this particular case, the amyloid state has evolved as a mechanism to carefully control the rate of active toxin that is dependent on the surrounding physiological conditions and therefore can control the entry and survival of the pathogen within the eukaryotic host. Apart from this essential function in pathogenesis, LLO seems to contribute to the internalization of this microorganism into host cells, is able to cause apoptosis, limits ROS production in the phagosome and induces mitochondrial fragmentation [126], making this toxin an example of the versatility of functional amyloids.

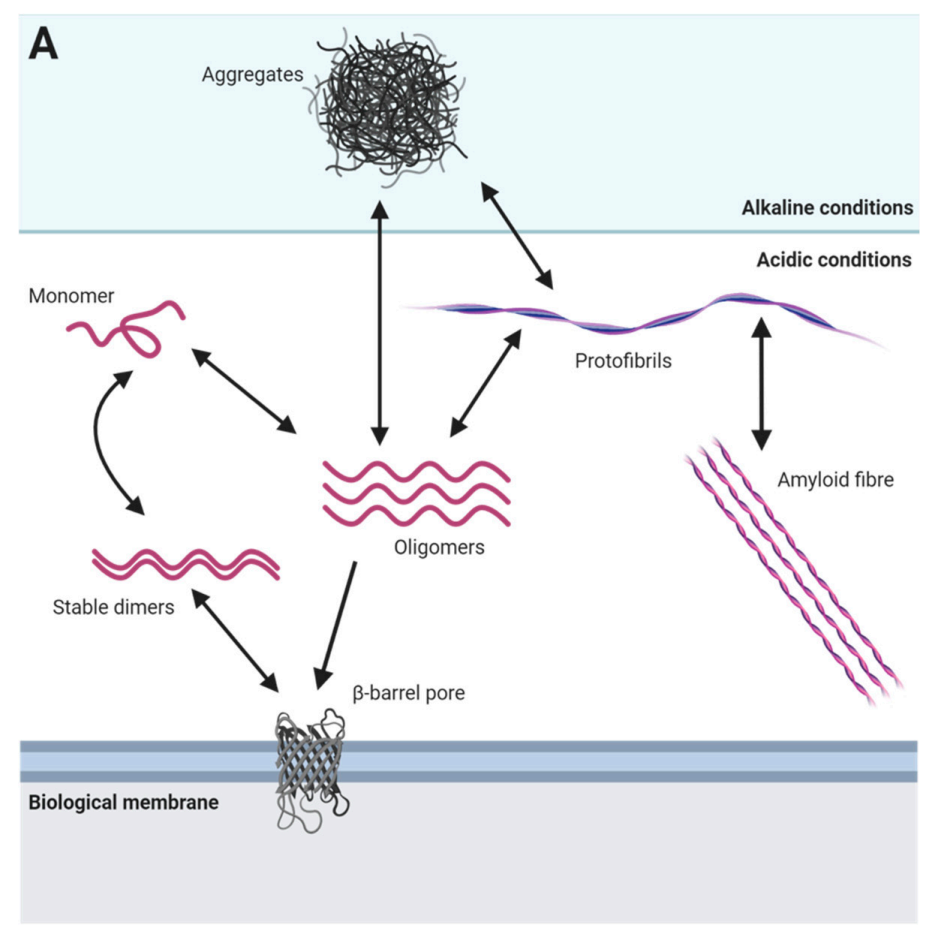

Figure 1. Cont. 


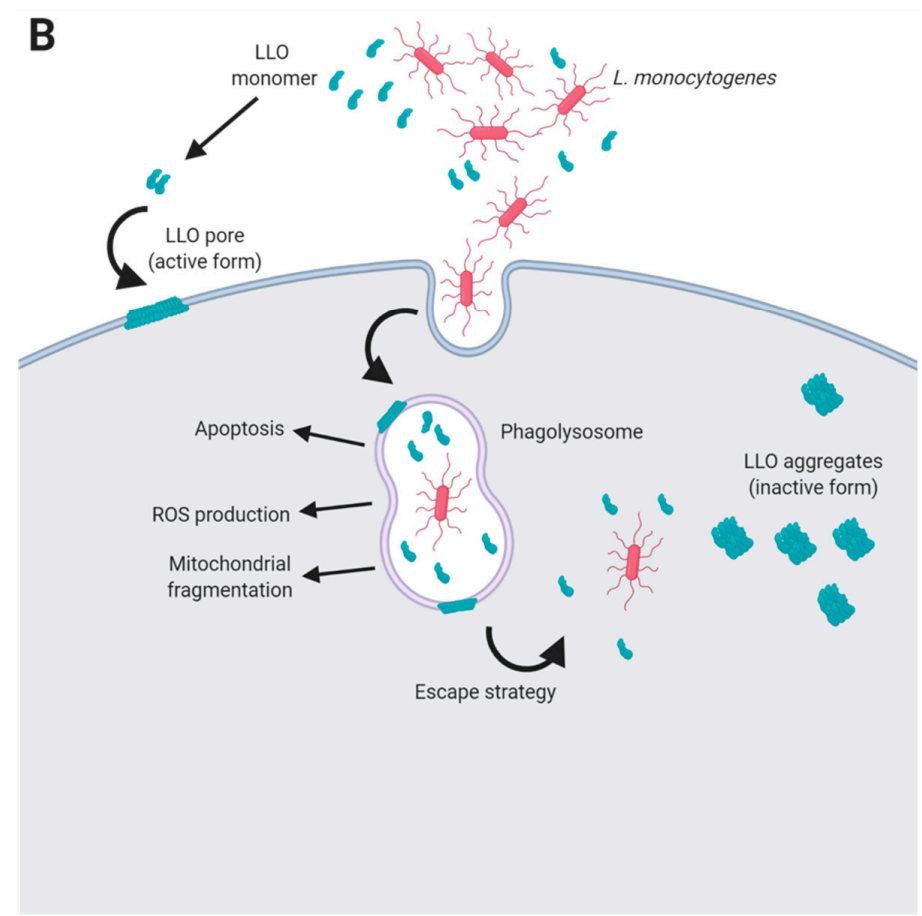

Figure 1. The role of functional amyloids as toxins. (A) Environmental conditions influence the aggregation state and kinetics of amyloid proteins. The folding of amyloid proteins into different structures is modulated by environmental conditions, i.e., $\mathrm{pH}$, as exemplified in this figure. Protein monomers are able to form stable dimers that adopt a beta-hairpin structure, which in contact with biological membranes switch to a $\beta$-barrel pore. Furthermore, monomers are able to assemble into oligomers that finally give rise to mature amyloid fibres. At non optimal conditions, misfolded monomers or oligomers tend to form amorphous aggregates that finally can lead to the formation of protofibrils or $\beta$-barrel pores when appropriate conditions are met. (B) Mechanism of action of LLO toxin of L. monocytogenes. The bacteria secretes monomers of LLO that form stable dimers that are able to oligomerize building pores through the interaction with biological membranes. Inside of the phagolysosome, the toxin is secreted by the bacteria, limiting ROS production and causing the lysis of the lysosome, which contributes to the survival of the pathogen. LLO is also implicated in apoptosis and mitochondrial fragmentation. At alkaline conditions, such as the ones found in the cytoplasm, LLO monomers are unable to polymerize and tend to form amyloid aggregates which inactivate the cytotoxic activity of the protein [125].

\section{The TasA Amyloid System in Bacillus spp.}

One of the best characterized amyloid systems is the one found in the soil-dwelling bacterium Bacillus subtilis, which has long been studied to describe the molecular mechanisms that lead to biofilm formation and other microbial processes [127]. The major protein component of the extracellular matrix [128] and the main amyloid component of this system is TasA (translocation-dependent antimicrobial spore component) due to the broad-spectrum antimicrobial properties reported in the pioneering studies [129]. Later, it was demonstrated that TasA is able to self-assemble into amyloid aggregates and fibres that serve as the structural scaffold of the extracellular matrix in B. subtilis biofilms [10]. These TasA amyloid fibres in B. subtilis are also composed of the accessory protein TapA (TasA anchoring and assembly protein), which participates in the assembly process by enhancing the polymerization of TasA subunits and anchoring the fibres to the cell surface in vivo [130]. Both proteins are essential for multicellularity and ECM production in B. subtilis, given that the absence of either of these proteins leads to defects in pellicle formation or colony architecture.

Structural studies have undoubtedly confirmed the amyloid nature of TasA, which transitions from a globular state to the characteristic robust fibres found in these multicellular communities [131]. Indeed, the existence of an amyloid core within the TasA sequence has been determined, indicating 
that not all the residues present in the protein are involved in the folding of the amyloid structure of TasA [132] (Figure 2A). Different environmental factors contribute to the transition of TasA from monomers to well-structured fibres. Native TasA aggregates directly purified from B. subtilis cells show a tendency to fibrillate under more acidic conditions and over hydrophobic surfaces [133], which is similar to the tendencies of some of the amyloids presented above. In fact, it has been shown that TasA interacts with synthetic bacterial membranes in vitro, which triggers the polymerization of the protein, influencing the morphology of the fibres [134]. These results show, once again, how environmental conditions can shape the morphology and properties of functional amyloids and how bacteria use the versatile structural and biochemical properties of amyloids to efficiently respond to sudden changes in their surroundings. Moreover, the partially disordered two-domain accessory protein TapA [135] is also a functional amyloid, in which only the first 57 amino acids seem to be important for biofilm architecture $[136,137]$. This protein has also been detected within the TasA amyloid fibres natively purified from $B$. subtilis cells and is able to self-assemble in vitro into aggregates that display the typical amyloid structure by $X$-ray diffraction analysis [132]. This finding, along with the fact that TapA enhances the polymerization of TasA in vitro without perturbing the global architecture of the amyloid filament, suggests that both proteins might co-assemble during biofilm formation [132], which would also explain the presence of TapA in TasA fibres isolated from B. subtilis cells (Figure 2A). The mechanism by which the two proteins interact has not yet been fully investigated. Recently, molecular dynamics approaches have suggested that the interactions between TasA and TapA rely on key amino acids located in their disordered C-terminal regions, which would explain the high proportion of intrinsic disorder that is present in these regions of both proteins [138].

TasA is also present in the closely related bacilli Bacillus amyloliquefaciens and Bacillus pumilus, in which the TasA protein has a high proportion of sequence identity in both bacilli [132]. In the group of bacilli that includes Bacillus cereus and other related pathogenic bacilli, such as Bacillus anthracis or Bacillus thuringiensis, tas $A$ is part of a genomic region that is analogous to that of B. subtilis and is involved in multicellular behaviour and biofilm formation [139]. However, TasA from B. cereus, contrary to what occurs in B. subtilis, lacks the C-terminal end, which does not affect the protein's ability to assemble into fibres that morphologically and structurally resemble those found in $B$. subtilis biofilms [132]. The group of B. cereus lacks the accessory protein TapA, but another protein called CalY is present in this system; CalY shares an important degree of sequence identity with TasA. CalY is not able to form fibres in vitro and seems to play a complementary role to TasA in the biofilm formation of B. cereus [139]. Nonetheless, the CalY protein displays the typical properties of amyloid proteins and has a structural fold similar to that observed for TasA. Interestingly, and similar to TapA, CalY facilitates the polymerization of $B$. cereus TasA without perturbing the structure of the filament, suggesting the possibility of co-assembly [132].

Apart from its structural role in the multicellular behaviour of Bacillus spp., these proteins play more complex roles in bacterial physiology. In B. subtilis, TasA has a dual role in the physiology of microorganisms: TasA maintains the cell membrane stability and prevents excess cell death under biofilm growth conditions (Figure 2A,B) [140]. Furthermore, during biofilm development, TasA acts as a signal to maintain a subset of motile cells within the bacterial population in a manner that is independent of the biofilm-motility switch, thereby promoting motility and repressing the expression of matrix genes (Figure 2C) [141]. In addition, TasA seems to mediate interactions with different organisms. For instance, this functional amyloid is important for the formation of dual species biofilms between $B$. subtilis and S. mutans. The expression of TasA is induced during this interspecies interaction is suggested to contribute to the early stages of the establishment of co-specific adhesion between the two species in a way that seems to be dependent on the presence of dextran, which is a major extracellular polysaccharide present in the extracellular matrix of S. mutans [142]. 


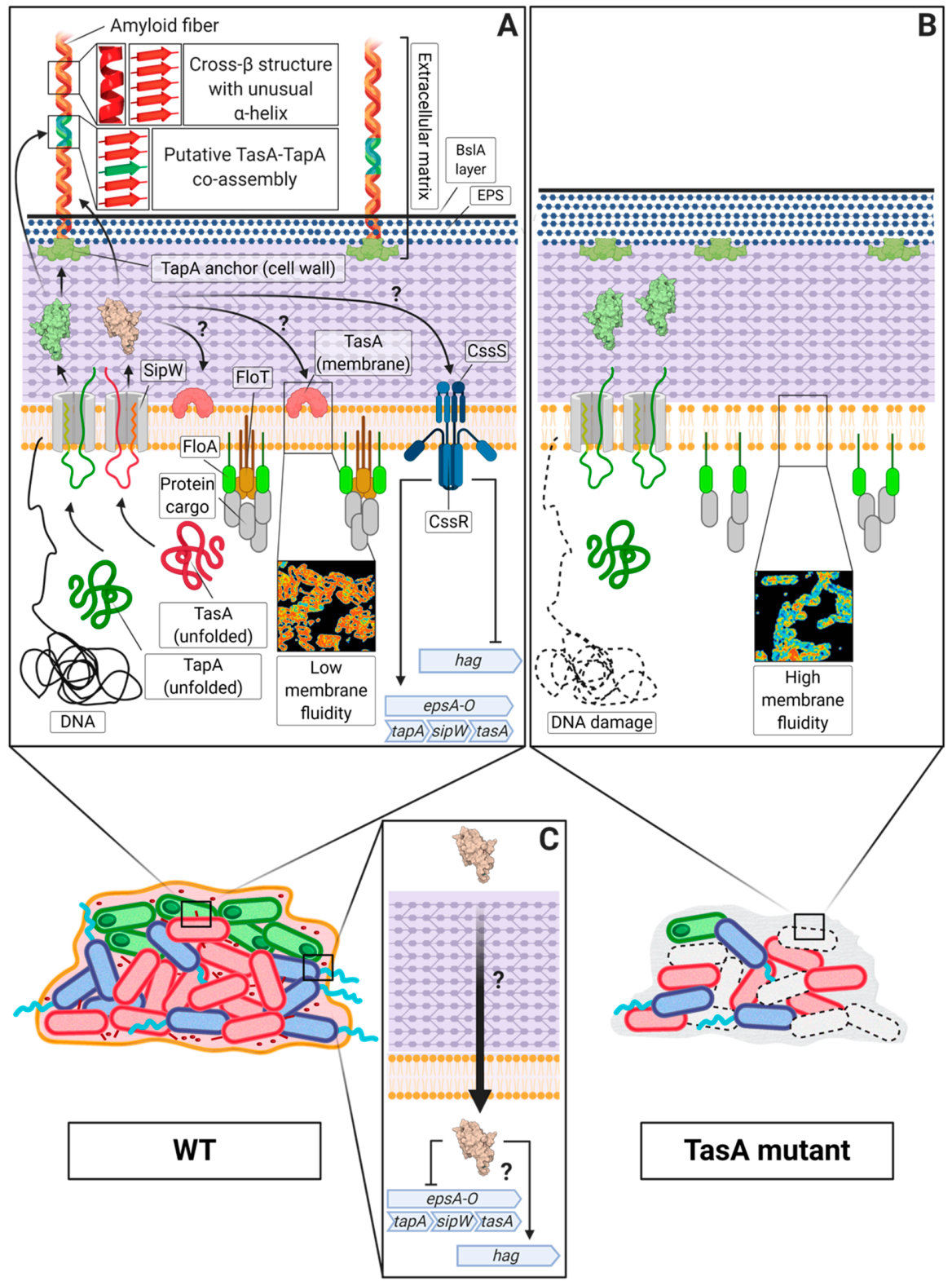

Figure 2. The TasA system in B. subtilis. The figure depicts the current knowledge regarding the TasA system in B. subtilis by showing two situations in the presence or absence of TasA. Biofilm formation requires the matrix proteins TasA and TapA, that are both essential for extracellular matrix production (ECM) and other cell functions, and the signal peptidase SipW. The biofilm schemes shown in the lower part of the figure include ECM producers (red), motile cells (blue), sporulating cells (green) and dead cells (dashed). (A). The TasA amyloid fibres provide structure to the ECM and exhibit a cross- $\beta$ structure with a particular proportion of $\alpha$-helix. These fibres are anchored to the cell surface by TapA, which also promotes TasA fibrillation and can be found as part of the fibres. In addition, TasA is also found in the cell membrane, where it maintains membrane stability, hypothetically, in proximity to functional membrane microdomains [140]. Under biofilm-inducing conditions, the expression of the matrix genes is maintained by the biofilm motility switch, which it has been recently reported to include the two-component response regulator CssS/CssR, that might sense TasA repressing the expression of flagellar genes [141]. (B). The absence of TasA leads to an increase of the cell death within the bacterial population, caused by a destabilization of the cell membrane and the subsequent alteration of membrane dynamics, which leads to the mislocalization of the flotillin FloT and other cellular disturbances such as DNA damage [140]. (C). In addition, TasA promotes motility by an unknown mechanism in a subset of the biofilm cells that allow for the proper expansion of the colony [141]. 
B. subtilis is a well-known biocontrol agent and natural enemy of pathogens and is often found in close association with plants [143]. It has been demonstrated that biofilm formation is important for the surface attachment of $B$. subtilis to different plant organs, roots or leaves, favouring antagonist activity [144]. The contribution of TasA to the persistence of B. subtilis cells over the plant phylloplane relies on at least three complementary traits: (i) mediating the early stages of the attachment of bacterial cells to the leaves, (ii) structurally ensuring the assembly of the ECM and (iii) preserving the viability of bacterial cells $[140,145]$. In addition, TasA is required for the attachment, biofilm formation and proliferation of $B$. subtilis in Arabidopsis thaliana and tomato roots [146,147]. Indeed, different plant substances, such as polysaccharides and organic acids, are able to trigger the expression of the tap $A$ operon, thereby inducing biofilm formation, which would explain the common presence of B. subtilis over plant surfaces [146]. In Bacillus velezensis QST713, a bacterial strain currently being used to protect the mushroom Agaricus bisporus against Trichoderma aggressivum f. europaeum, another fungal competitor, the expression of TasA and other matrix genes contributes to biofilm formation in compost, which, reciprocally, favours the synthesis of secondary metabolites and antimicrobials [148]. From the B. cereus group side, the orthologue of TasA found in B. cereus CR4, a strain isolated from activated sludges, shows remarkable bioflocculant activity, which makes this microorganism a good candidate for harvesting microalgae, which is an emerging strategy in the production of biofuels [149]. In B. thuringiensis, CalY has been shown to be required for the attachment of bacteria to HeLa cells and for the virulence against the wax moth Galleria melonella [150]. However, at the end of the stationary phase, the presence of CalY mostly shifts from the cell surface to the extracellular medium, where the protein is able to polymerize in the form of fibres that support biofilm formation. These results demonstrate the many functionalities that the TasA amyloid system and its orthologues have in the biology and ecology of Bacillus spp. and highlight the notion of multiple purposes traditionally attributed to functional amyloids.

\section{Amyloid Cross-Seeding as a Molecular Crosstalk Mechanism in Bacteria?}

Amyloid proteins exhibit a tendency to aggregate, which is one of their defining features. The formation of homologous aggregates and fibres, which are those composed only of one amyloid polypeptide, have been traditionally the most studied. However, the common structural and biochemical properties of amyloid proteins allow for heterologous interactions in a process known as cross-seeding [151]. Cross-seeding and heterologous amyloid aggregates have been well studied in pathological amyloids, such as $\mathrm{A} \beta_{42}, \alpha$-synuclein and tau, which are different amyloid peptides that are involved in Alzheimer's disease [152]. It has been demonstrated in vivo and in vitro how aggregated $A \beta_{42}$ strongly influences tau aggregation and the appearance of tau seeds that are able to trigger the propagation of tau pathology in vivo [153]. Similarly, $\alpha$-synuclein fibrils are able to induce the formation of neurofibrillary aggregates by cross-seeding with tau intracellularly [154].

In contrast, little is known about cross-seeding between different functional bacterial amyloids, and very few cases have been reported in which cross-seeding occurs to serve a specific biological purpose. An example of this has been studied in the gram-negative bacterium E. coli. In this microorganism, the curli, which are extracellular proteinaceous filaments involved in biofilm formation and adhesion to different biotic and abiotic surfaces [155-158], exhibit an amyloid nature. These fibres are composed of two amyloid proteins: CsgA, which is the major curli subunit, and CsgB, which acts as a nucleator, favouring the assembly of curli filaments $[8,159]$. In vitro experiments have demonstrated that CsgA is a rather promiscuous protein that is able to cross-seed with CsgA orthologues present in other bacterial species (Salmonella typhimurium, Citrobacter koseri or Shewanella oneidensis), even when the sequence identity between these curli orthologues is as low as 30\%. Interestingly, this cross-seeding mechanism is also evidenced in the interaction between E. coli and S. typhimurium, where the CsgA subunit produced and secreted by E. coli can complement the defects of a csgA mutant of S. typhimurium and vice versa. Similar results were also obtained in the study of the CsgB subunit. This complementation restores the adhesion capacity of the mixed community and promotes dual-species biofilms between 
the two bacteria, demonstrating how amyloid cross-seeding can modulate not only intraspecies but also interspecies microbial physiology and ecology [160].

A number of experimental studies also suggest the existence of intra- and interspecies complementation of functional amyloids of Bacillus. First, biofilm formation is restored in mixed cultures of eps and tas $A$ isogenic single mutants, suggesting a structural role of TasA provided by the eps mutant for the benefit of the community [130]. However, unlike curli of gram-negative bacteria, it seems more likely that the two subunits involved in TasA amyloid fibre formation (TapA and TasA) have to be produced by the same cell to fulfil their functionality, and this is supported by two complementary experimental studies: (i) the co-culture of $\operatorname{tas} A$ and $\operatorname{tap} A$ does not produce wrinkled colonies typical of a WT biofilm [130], and (ii) purified TasA does not rescue biofilm formation in a tap $A$ mutant [132]. The precise mechanism that drives the collaboration of the two proteins in fibre assembly remains to be determined. Interestingly, and in agreement with this finding of intraspecies interaction, the chromosomal region containing TasA and CalY in B. cereus rescues biofilm formation in a B. subtilis mutant for the whole tapA operon. Similarly, and more specifically, B. cereus TasA, when heterologously expressed in B. subtilis, was able to cause the same reversion. The formation of TasA fibres in both B. subtilis backgrounds and the Congo red staining of the colony were indicative of the preservation of the amyloid nature of B. cereus TasA expressed in B. subtilis [139]. Further structural and functional studies with purified proteins from both species will shed light on the exact molecular mechanism of interspecies complementation.

In the gram-positive bacterium S. aureus, the PSMs described in the above section are involved in biofilm formation [11,79]. Recent studies suggest that each individual PSM exhibits a unique behaviour in terms of aggregation and amyloid formation. Moreover, it has been shown that, in vitro, PSMs have the ability to interact with one another by cross-seeding, in which preformed seeds of one PSM are able to induce polymerization of other PSMs. In fact, PSMs exhibit a certain degree of specificity in their cross-seeding ability; for instance, PSM $\alpha 3$ seeds promote only self-aggregation and aggregation of PSM $\alpha 1$, PSM $\beta 1$ is able to cross-seed only with PSM $\alpha 1$ and PSM $\beta 2$, and PSM $\beta 2$ seeds accelerate only the aggregation of PSM $\alpha 1$, with some mild effects on PSM $\beta 1$, PSM $\alpha 2$ and the $\delta$ toxin. PSM $\alpha 1$ seems to be less strict in its ability to cross-seed than the other PSMs and can induce aggregation in all of them [161]. Overall, these results suggest a possible interplay of all these peptides in the multicellular behaviour of $S$. aureus; however, more experimental evidence is needed to associate a biological function with this cross-seeding activity in the context of biofilm formation.

\section{Concluding Remarks}

In bacteria, research efforts have focused on the role of functional amyloids as structural scaffolds within the biofilms, however, additional roles in bacterial physiology and interaction with hosts are currently being discovered. In Gram-positive bacteria, there is a vast diversity of amyloid systems, each one with its own protein components and peculiarities in the process of polymerization. This biochemical variety increases the chances of finding new functions associated with amyloid proteins or the amyloid systems themselves. The tendency shown by these proteins to interact with each other in different biological contexts makes cross-seeding a potential mechanism for the diversification of communication between different species and therefore the structure of heterogenous microbial communities. This biological promiscuity can also be translated to the interaction with eucaryotes, where amyloids may induce or repress the polymerization of their eucaryotic siblings, thus introducing different responses at a cellular, immunological or physiological level. These are exciting questions that will provide us with new and undescribed roles of microbial amyloids, knowledge that will additionally help understanding of the real impact of this family of proteins in the ecology of gram-positive bacteria.

Funding: This research was funded by ERC Starting Grant (BacBio 637971) and Plan Nacional de I+D+I of Ministerio de Ciencia e Innovación (AGL2016-78662-R and PID2019-107724GB-I00). Ana María Álvarez Mena is the recipient of an FPI fellowship (BES-2017-081275). 
Conflicts of Interest: The authors declare no conflict of interest. The funders had no role in the design of the study; in the collection, analyses, or interpretation of data; in the writing of the manuscript, or in the decision to publish the results.

\section{References}

1. Fowler, D.M.; Koulov, A.V.; Balch, W.E.; Kelly, J.W. Functional amyloid-From bacteria to humans. Trends Biochem. Sci. 2007, 32, 217-224. [CrossRef] [PubMed]

2. Sipe, J.D.; Cohen, A.S. Review: History of the amyloid fibril. J. Struct. Biol. 2000, 130, 88-98.

3. Jaunmuktane, Z.; Mead, S.; Ellis, M.; Wadsworth, J.D.F.; Nicoll, A.J.; Kenny, J.; Launchbury, F.; Linehan, J.; Richard-Loendt, A.; Walker, A.S.; et al. Evidence for human transmission of amyloid-beta pathology and cerebral amyloid angiopathy. Nature 2015, 525, 247-250. [CrossRef] [PubMed]

4. Fritschi, S.K.; Cintron, A.; Ye, L.; Mahler, J.; Buhler, A.; Baumann, F.; Neumann, M.; Nilsson, K.P.R.; Jammarstrom, P.; Walker, L.K.; et al. Abeta seeds resist inactivation by formaldehyde. Acta Neuropathol. 2014, 128, 477-484. [CrossRef]

5. Wosten, H.A.; de Vocht, M.L. Hydrophobins, the fungal coat unravelled. Biochim. Biophys. Acta 2000, 1469, 79-86. [CrossRef]

6. Sgro, G.G.; Ficarra, F.A.; Dunger, G.; Scarpeci, T.E.; Valle, E.M.; Cortadi, A.; Orellano, E.G.; Gotting, N.; Ottado, J. Contribution of a harpin protein from Xanthomonas axonopodis pv. citri to pathogen virulence. Mol. Plant Pathol. 2012, 13, 1047-1059. [CrossRef]

7. Shahnawaz, M.; Soto, C. Microcin amyloid fibrils A are reservoir of toxic oligomeric species. J. Biol. Chem. 2012, 287, 11665-11676. [CrossRef]

8. Chapman, M.R.; Robinson, L.S.; Pinkner, J.S.; Roth, R.; Heuser, J.; Hammar, M.; Normark, S.; Hultgren, S.J. Role of Escherichia coli curli operons in directing amyloid fiber formation. Science 2002, 295, 851-855. [CrossRef]

9. Dueholm, M.S.; Petersen, S.V.; Sønderkaer, M.; Larsen, P.; Christiansen, G.; Hein, K.L.; Enghild, J.J.; Nielsen, J.L.; Nielsen, K.L.; Nielsen, P.H.; et al. Functional amyloid in Pseudomonas. Mol. Microbiol. 2010, 77, 1009-1020. [CrossRef]

10. Romero, D.; Aguilar, C.; Losick, R.; Kolter, R. Amyloid fibers provide structural integrity to Bacillus subtilis biofilms. Proc. Natl. Acad. Sci. USA 2010, 107, 2230-2234. [CrossRef]

11. Schwartz, K.; Syed, A.K.; Stephenson, R.E.; Rickard, A.H.; Boles, B.R. Functional amyloids composed of phenol soluble modulins stabilize staphylococcus aureus biofilms. PLoS Pathog. 2012, 8, e1002744. [CrossRef] [PubMed]

12. Alteri, C.J.; Xicohténcatl-Cortes, J.; Hess, S.; Caballero-Olin, G.; Giron, J.A.; Friedman, R.L. Mycobacterium tuberculosis produces pili during human infection. Proc. Natl. Acad. Sci. USA 2007, 104, 5145-5150. [CrossRef]

13. Kummer, M.P.; Maruyama, H.; Huelsmann, C.; Baches, S.; Weggen, S.; Koo, E.H. Formation of Pmel17 amyloid is regulated by juxtamembrane metalloproteinase cleavage, and the resulting C-terminal fragment is a substrate for $\gamma$-secretase. J. Biol. Chem. 2008, 284, 2296-2306. [CrossRef] [PubMed]

14. Uversky, V.N.; Fink, A.L. Conformational constraints for amyloid fibrillation: The importance of being unfolded. Biochim. Biophys. Acta Proteins Proteom. 2004, 1698, 131-153. [CrossRef] [PubMed]

15. Groenning, M. Binding mode of Thioflavin T and other molecular probes in the context of amyloid fibrils-Current status. J. Chem. Biol. 2010, 3, 1-18. [CrossRef]

16. Eisert, R.; Felau, L.; Brown, L.R. Methods for enhancing the accuracy and reproducibility of Congo red and thioflavin T assays. Anal. Biochem. 2006, 353, 144-146. [CrossRef]

17. Shewmaker, F.; McGlinchey, R.P.; Wickner, R.B. Structural insights into functional and pathological amyloid. J. Biol. Chem. 2011, 286, 16533-16540. [CrossRef]

18. Friedland, R.P.; Chapman, M.R. The role of microbial amyloid in neurodegeneration. PLoS Pathog. 2017, 13, e1006654. [CrossRef]

19. Sitaras, C.; Naghavi, M.; Herrington, M.B. Sodium dodecyl sulfate-agarose gel electrophoresis for the detection and isolation of amyloid curli fibers. Anal. Biochem. 2011, 408, 328-331. [CrossRef]

20. Smith, J.F.; Knowles, T.P.J.; Dobson, C.M.; Macphee, C.E.; Welland, M.E. Characterization of the nanoscale properties of individual amyloid fibrils. Proc. Natl. Acad. Sci. USA 2006, 103, 15806-15811. [CrossRef] 
21. Knowles, T.; Fitzpatrick, A.W.; Meehan, S.; Mott, H.R.; Vendruscolo, M.; Dobson, C.M.; Welland, M.E. Role of intermolecular forces in defining material properties of protein nanofibrils. Science 2007, 318, 1900-1903. [CrossRef] [PubMed]

22. Larsen, P.; Nielsen, J.L.; Dueholm, M.S.; Wetzel, R.; Otzen, D.; Nielsen, P.H. Amyloid adhesins are abundant in natural biofilms. Environ. Microbiol. 2007, 9, 3077-3090. [CrossRef] [PubMed]

23. Larsen, P.; Nielsen, J.L.; Otzen, D.; Nielsen, P.H. Amyloid-like adhesins produced by floc-forming and filamentous bacteria in activated sludge. Appl. Environ. Microbiol. 2008, 74, 1517-1526. [CrossRef] [PubMed]

24. Dueholm, M.S.; Albertsen, M.; Otzen, D.E.; Nielsen, P.H. Curli functional amyloid systems are phylogenetically widespread and display large diversity in operon and protein structure. PLoS ONE 2012, 7, e51274. [CrossRef] [PubMed]

25. Olsen, A.; Jonsson, A.; Normark, S. Fibronectin binding mediated by a novel class of surface organelles on Escherichia coli. Nature 1989, 338, 652-655. [CrossRef] [PubMed]

26. Zogaj, X.; Bokranz, W.; Nimtz, M.; Römling, U. Production of cellulose and curli fimbriae by members of the family enterobacteriaceae isolated from the human gastrointestinal tract. Infect. Immun. 2003, 71, 4151-4158. [CrossRef]

27. Gibson, D.L.; White, A.P.; Rajotte, C.M.; Kay, W.W. AgfC and AgfE facilitate extracellular thin aggregative fimbriae synthesis in Salmonella Enteritidis. Microbiology 2007, 153, 1131-1140. [CrossRef]

28. Elliot, M.A.; Karoonuthaisiri, N.; Huang, J.; Bibb, M.J.; Cohen, N.S.; Kao, K.M.; Buttner, M.J. The chaplins: A family of hydrophobic cell-surface proteins involved in aerial mycelium formation in Streptomyces coelicolor. Genes Dev. 2003, 17, 1727-1740. [CrossRef]

29. Oli, M.W.; Otoo, H.N.; Crowley, P.J.; Heim, K.P.; Nascimento, M.M.; Ramsook, C.B.; Lipke, P.N.; Brady, L.J. Functional amyloid formation by Streptococcus mutans. Microbiology 2012, 158, 2903-2916. [CrossRef]

30. Oh, J.; Kim, J.-G.; Jeon, E.; Yoo, C.-H.; Moon, J.S.; Rhee, S.; Hwang, I. Amyloidogenesis of type III-dependent harpins from plant pathogenic bacteria. J. Biol. Chem. 2007, 282, 13601-13609. [CrossRef]

31. Molina-García, L.; Gasset-Rosa, F.; Álamo, M.M.-D.; Fernández-Tresguerres, M.E.; De La Espina, S.M.D.; Lurz, R.; Giraldo, R. Functional amyloids as inhibitors of plasmid DNA replication. Sci. Rep. 2016, 6, 25425. [CrossRef] [PubMed]

32. Rouse, S.L.; Matthews, S.J.; Dueholm, M.S. Ecology and biogenesis of functional amyloids in pseudomonas. J. Mol. Biol. 2018, 430, 3685-3695. [CrossRef] [PubMed]

33. Salinas, N.; Povolotsky, T.L.; Landau, M.; Kolodkin-Gal, I. Emerging roles of functional bacterial amyloids in gene regulation, toxicity, and immunomodulation. Microbiol. Mol. Biol. Rev. 2020, 85. [CrossRef] [PubMed]

34. Davies, D.G. Understanding biofilm resistance to antibacterial agents. Nat. Rev. Drug Discov. 2003, 2, 114-122. [CrossRef] [PubMed]

35. Flemming, H.-C.; Wingender, J. The biofilm matrix. Nat. Rev. Genet. 2010, 8, 623-633. [CrossRef] [PubMed]

36. Flemming, H.-C.; Wingender, H.-C.F.J.; Szewzyk, U.; Steinberg, P.; A Rice, S.; Kjelleberg, S.A.R.S. Biofilms: An emergent form of bacterial life. Nat. Rev. Genet. 2016, 14, 563-575. [CrossRef] [PubMed]

37. Taglialegna, A.; Lasa, I.; Valle, J. Amyloid structures as biofilm matrix scaffolds. J. Bacteriol. 2016, 198, 2579-2588. [CrossRef]

38. Serra, D.O.; Richter, A.M.; Klauck, G.; Mika, F.; Hengge, R. Microanatomy at cellular resolution and spatial order of physiological differentiation in a bacterial biofilm. mBio 2013, 4, e00103-13. [CrossRef]

39. Nguyen, P.Q.; Botyanszki, Z.; Tay, P.K.R.; Joshi, N.S. Programmable biofilm-based materials from engineered curli nanofibres. Nat. Commun. 2014, 5, 4945. [CrossRef]

40. Knowles, T.P.J.; Mezzenga, R. Amyloid fibrils as building blocks for natural and artificial functional materials. Adv. Mater. 2016, 28, 6546-6561. [CrossRef]

41. Horvath, I.; Weise, C.F.; Andersson, E.K.; Chorell, E.; Sellstedt, M.; Bengtsson, C.; Olofsson, A.; Hultgren, S.J.; Chapman, M.R.; Wolf-Watz, M.; et al. Mechanisms of protein oligomerization: Inhibitor of functional amyloids templates $\alpha$-Synuclein fibrillation. J. Am. Chem. Soc. 2012, 134, 3439-3444. [CrossRef] [PubMed]

42. Claessen, D.; Rink, R.; De Jong, W.; Siebring, J.; De Vreugd, P.; Boersma, F.H.; Dijkhuizen, L.; Wösten, H.A. A novel class of secreted hydrophobic proteins is involved in aerial hyphae formation in Streptomyces coelicolor by forming amyloid-like fibrils. Genes Dev. 2003, 17, 1714-1726. [CrossRef] [PubMed]

43. Elliot, M.A.; Talbot, N.J. Building filaments in the air: Aerial morphogenesis in bacteria and fungi. Curr. Opin. Microbiol. 2004, 7, 594-601. [CrossRef] [PubMed]

44. Willey, J.M.; Willems, A.; Kodani, S.; Nodwell, J. Morphogenetic surfactants and their role in the formation of aerial hyphae in Streptomyces coelicolor. Mol. Microbiol. 2005, 59, 731-742. [CrossRef] [PubMed] 
45. Bentley, S.D.; Chater, K.F.; Cerdeno-Tarraga, A.M.; Challis, G.L.; Thomson, N.R.; James, K.D.; Harris, D.E.; Quail, M.A.; Kieser, H.; Herper, D.; et al. Complete genome sequence of the model actinomycete Streptomyces coelicolor A3(2). Nature 2002, 417, 141-147. [CrossRef] [PubMed]

46. Ikeda, H.; Ishikawa, J.; Hanamoto, A.; Shinose, M.; Kikuchi, H.; Shiba, T.; Sakaki, Y.; Hattori, M.; Ōmura, S. Complete genome sequence and comparative analysis of the industrial microorganism Streptomyces avermitilis. Nat. Biotechnol. 2003, 21, 526-531. [CrossRef]

47. Ohnishi, Y.; Ishikawa, J.; Hara, H.; Suzuki, H.; Ikenoya, M.; Ikeda, H.; Yamashita, A.; Hattori, M.; Horinouchi, S. Genome sequence of the streptomycin-producing microorganism-Streptomyces griseus-IFO 13350. J. Bacteriol. 2008, 190, 4050. [CrossRef]

48. Di Berardo, C.; Capstick, D.S.; Bibb, M.J.; Findlay, K.C.; Buttner, M.J.; Elliot, M.A. Function and redundancy of the Chaplin cell surface proteins in aerial hypha formation, rodlet assembly, and viability in streptomyces coelicolor. J. Bacteriol. 2008, 190, 5879-5889. [CrossRef]

49. De Jong, W.; Wosten, H.A.B.; Dijkhuizen, L.; Claessen, D. Attachment of Streptomyces coelicolor is mediated by amyloidal fimbriae that are anchored to the cell surface via cellulose. Mol. Microbiol. 2009, 73, 1128-1140. [CrossRef]

50. Schneewind, O.; Missiakas, D.M. Protein secretion and surface display in Gram-positive bacteria. Philos. Trans. R. Soc. B Biol. Sci. 2012, 367, 1123-1139. [CrossRef]

51. Duong, A.; Capstick, D.S.; Di Berardo, C.; Findlay, K.C.; Hesketh, A.; Hong, H.-J.; Elliot, M.A. Aerial development in Streptomyces coelicolor requires sortase activity. Mol. Microbiol. 2012, 83, 992-1005. [CrossRef] [PubMed]

52. Pastor, M.T.; Esteras-Chopo, A.; Serrano, L. Hacking the code of amyloid formation: The amyloid stretch hypothesis. Prion 2007, 1, 9-14. [CrossRef] [PubMed]

53. Petrus, M.; Claessen, D. Pivotal roles for Streptomyces cell surface polymers in morphological differentiation, attachment and mycelial architecture. Antonie Leeuwenhoek 2014, 106, 127-139. [CrossRef] [PubMed]

54. Capstick, D.S.; Jomaa, A.; Hanke, C.; Ortega, J.; Elliot, M.A. Dual amyloid domains promote differential functioning of the chaplin proteins during Streptomyces aerial morphogenesis. Proc. Natl. Acad. Sci. USA 2011, 108, 9821-9826. [CrossRef]

55. Claessen, D.; Wosten, H.A.B.; van Keulen, G.; Faber, O.G.; Alves, A.M.C.R.; Maijer, W.G.; Dijkhuizen, L. Two novel homologous proteins of Streptomyces coelicolor and Streptomyces lividans are involved in the formation of the rodlet layer and mediate attachment to a hydrophobic surface. Mol. Microbiol. 2002, 44, 1483-1492. [CrossRef]

56. Claessen, D.; Stokroos, I.; Deelstra, H.J.; Penninga, N.A.; Bormann, C.; Salas, J.A.; Dijkhuizen, L.; Wösten, H.A.B. The formation of the rodlet layer of streptomycetes is the result of the interplay between rodlins and chaplins. Mol. Microbiol. 2004, 53, 433-443. [CrossRef]

57. Yang, W.; Willemse, J.; Sawyer, E.B.; Lou, F.; Gong, W.; Zhang, H.; Gras, S.L.; Claessen, D.; Perrett, S. The propensity of the bacterial rodlin protein RdlB to form amyloid fibrils determines its function in Streptomyces coelicolor. Sci. Rep. 2017, 7, 42867. [CrossRef]

58. Kodani, S.; Hudson, M.E.; Durrant, M.C.; Buttner, M.J.; Nodwell, J.R.; Willey, J.M. The SapB morphogen is a lantibiotic-like peptide derived from the product of the developmental gene ramS in Streptomyces coelicolor. Proc. Natl. Acad. Sci. USA 2004, 101, 11448-11453. [CrossRef]

59. De Jong, W.; Vijgenboom, E.; Dijkhuizen, L.; Wösten, H.A.B.; Claessen, D. SapB and the rodlins are required for development of Streptomyces coelicolor in high osmolarity media. FEMS Microbiol. Lett. 2012, 329, 154-159. [CrossRef]

60. Dragos, A.; Kovács, Á.T.; Claessen, D. The role of functional amyloids in multicellular growth and development of gram-positive bacteria. Biomolecules 2017, 7, 60. [CrossRef]

61. Kodani, S.; Lodato, M.A.; Durrant, M.C.; Picart, F.; Willey, J.M. SapT, a lanthionine-containing peptide involved in aerial hyphae formation in the streptomycetes. Mol. Microbiol. 2005, 58, 1368-1380. [CrossRef] [PubMed]

62. Willey, J.; Santamaría, R.I.; Guijarro, J.; Geistlich, M.; Losick, R. Extracellular complementation of a developmental mutation implicates a small sporulation protein in aerial mycelium formation by S. coelicolor. Cell 1991, 65, 641-650. [CrossRef]

63. Otto, M. Staphylococcal biofilms. Curr. Top. Microbiol. Immunol. 2008, 322, 207-228. [PubMed]

64. Mehlin, C.; Headley, C.M.; Klebanoff, S.J. An inflammatory polypeptide complex from staphylococcus epidermidis: Isolation and characterization. J. Exp. Med. 1999, 189, 907-918. [CrossRef] 
65. Tsompanidou, E.; Denham, E.L.; Becher, D.; De Jong, A.; Buist, G.; Van Oosten, M.; Manson, W.L.; Back, J.W.; Van Dijl, J.M.; Dreisbach, A. Distinct roles of phenol-soluble modulins in spreading of Staphylococcus aureus on wet surfaces. Appl. Environ. Microbiol. 2013, 79, 886-895. [CrossRef]

66. Periasamy, S.; Joo, H.-S.; Duong, A.C.; Bach, T.-H.L.; Tan, V.Y.; Chatterjee, S.S.; Cheung, G.Y.C.; Otto, M. How Staphylococcus aureus biofilms develop their characteristic structure. Proc. Natl. Acad. Sci. USA 2012, 109, 1281-1286. [CrossRef]

67. Vuong, C.; Kocianova, S.; Yao, Y.; Carmody, A.B.; Otto, M. Increased colonization of indwelling medical devices by quorum-sensing mutants of Staphylococcus epidermidis in vivo. J. Infect. Dis. 2004, 190, 1498-1505. [CrossRef]

68. Vuong, C.; Dürr, M.; Carmody, A.B.; Peschel, A.; Klebanoff, S.J.; Otto, M. Regulated expression of pathogen-associated molecular pattern molecules in Staphylococcus epidermidis: Quorum-sensing determines pro-inflammatory capacity and production of phenol-soluble modulins. Cell. Microbiol. 2004, 6, 753-759. [CrossRef]

69. Wang, R.; Braughton, K.R.; Kretschmer, D.; Bach, T.H.L.; Queck, S.Y.; Li, M.; Kennedy, A.D.; Dorward, D.W.; Klebanoff, S.J.; Peschel, A.; et al. Identification of novel cytolytic peptides as key virulence determinants for community-associated MRSA. Nat. Med. 2007, 13, 1510-1514. [CrossRef]

70. Yao, Y.; Sturdevant, D.E.; Otto, M. Genomewide analysis of gene expression in Staphylococcus epidermidis biofilms: Insights into the pathophysiology of S. epidermidisBiofilms and the role of Phenol-soluble modulins in formation of biofilms. J. Infect. Dis. 2005, 191, 289-298. [CrossRef]

71. Rautenberg, M.; Joo, H.; Otto, M.; Peschel, A. Neutrophil responses to staphylococcal pathogens and commensals via the formyl peptide receptor 2 relates to phenol-soluble modulin release and virulence. FASEB J. 2011, 25, 1254-1263. [CrossRef] [PubMed]

72. Cogen, A.L.; Yamasaki, K.; Sanchez, K.M.; Dorschner, R.A.; Lai, Y.; MacLeod, D.T.; Torpey, J.W.; Otto, M.; Nizet, V.; Kim, J.E.; et al. Selective antimicrobial action is provided by Phenol-soluble modulins derived from Staphylococcus epidermidis, a normal resident of the skin. J. Investig. Dermatol. 2010, 130, 192-200. [CrossRef] [PubMed]

73. Janzon, L.; Löfdahl, S.; Arvidson, S. Identification and nucleotide sequence of the delta-lysin gene, hld, adjacent to the accessory gene regulator (agr) of Staphylococcus aureus. Mol. Genet. Genom. 1989, 219, 480-485. [CrossRef] [PubMed]

74. Queck, S.Y.; Jameson-Lee, M.; Villaruz, A.E.; Bach, T.-H.L.; Khan, B.A.; Sturdevant, D.E.; Ricklefs, S.M.; Li, M.; Otto, M. RNAIII-independent target gene control by the agr quorum-sensing system: Insight into the evolution of virulence regulation in Staphylococcus aureus. Mol. Cell 2008, 32, 150-158. [CrossRef]

75. Joo, H.-S.; Cheung, G.Y.C.; Otto, M. Antimicrobial activity of community-associated Methicillinresistant Staphylococcus aureus is caused by Phenol-soluble modulin derivatives. J. Biol. Chem. 2011, 286, 8933-8940. [CrossRef]

76. Kretschmer, D.; Gleske, A.K.; Rautenberg, M.; Wang, R.; Köberle, M.; Bohn, E.; Schöneberg, T.; Rabiet, M.-J.; Boulay, F.; Klebanoff, S.J.; et al. Human formyl peptide receptor 2 senses highly pathogenic Staphylococcus aureus. Cell Host Microbe 2010, 7, 463-473. [CrossRef]

77. Nakamura, Y.; Oscherwitz, J.; Cease, K.B.; Chan, S.M.; Muñoz-Planillo, R.; Hasegawa, M.; Villaruz, A.E.; Cheung, G.Y.C.; McGavin, M.J.; Travers, J.B.; et al. Staphylococcus $\delta$-toxin induces allergic skin disease by activating mast cells. Nat. Cell Biol. 2013, 503, 397-401. [CrossRef]

78. Cheung, G.Y.C.; Kretschmer, D.; Queck, S.Y.; Joo, H.S.; Wang, R.; Duong, A.C.; Nguyen, T.H.; Bach, T.H.L.; Porter, A.R.; DeLeo, F.R.; et al. Insight into structure-function relationship in phenol-soluble modulins using an alanine screen of the phenol-soluble modulin (PSM) $\alpha 3$ peptide. FASEB J. 2014, 28, 153-161. [CrossRef]

79. Marinelli, P.; Pallares, I.; Navarro, S.; Ventura, S. Dissecting the contribution of Staphylococcus aureus $\alpha$-phenol-soluble modulins to biofilm amyloid structure. Sci. Rep. 2016, 6, 34552. [CrossRef]

80. Salinas, N.; Colletier, J.P.; Moshe, A.; Landau, M. Extreme amyloid polymorphism in Staphylococcus aureus virulent PSMalpha peptides. Nat. Commun. 2018, 9, 3512.

81. Cheung, G.Y.; Otto, M. The potential use of toxin antibodies as a strategy for controlling acute Staphylococcus aureus infections. Expert Opin. Ther. Targets 2012, 16, 601-612. [CrossRef]

82. Tayeb-Fligelman, E.; Tabachnikov, O.; Moshe, A.; Goldshmidt-Tran, O.; Sawaya, M.R.; Coquelle, N.; Colletier, J.P.; Landau, M. The cytotoxic Staphylococcus aureus PSM $\alpha 3$ reveals a cross- $\alpha$ amyloid-like fibril. Science 2017, 355, 831. [CrossRef] 
83. Cassat, J.E.; Hammer, N.D.; Campbell, J.P.; Benson, M.A.; Perrien, D.S.; Mrak, L.N.; Smeltzer, M.S.; Torres, V.J.; Skaar, E.P. A secreted bacterial protease tailors the Staphylococcus aureus virulence repertoire to modulate bone remodeling during psteomyelitis. Cell Host Microbe 2013, 13, 759-772. [CrossRef]

84. Rasigade, J.-P.; Trouillet-Assant, S.; Ferry, T.; Diep, B.A.; Sapin, A.; Lhoste, Y.; Ranfaing, J.; Badiou, C.; Benito, Y.; Bes, M.; et al. PSMs of hypervirulent Staphylococcus aureus act as intracellular toxins that kill infected osteoblasts. PLoS ONE 2013, 8, e63176. [CrossRef] [PubMed]

85. Cheung, G.Y.C.; Duong, A.C.; Otto, M. Direct and synergistic hemolysis caused by Staphylococcus phenol-soluble modulins: Implications for diagnosis and pathogenesis. Microbes Infect. 2012, 14, 380-386. [CrossRef] [PubMed]

86. Cogen, A.L.; Yamasaki, K.; Muto, J.; Sanchez, K.M.; Alexander, L.C.; Tanios, J.; Lai, Y.; Kim, J.E.; Nizet, V.; Gallo, R.L. Staphylococcus epidermidis antimicrobial delta-toxin (phenol-soluble modulin-gamma) cooperates with host antimicrobial peptides to kill group A Streptococcus. PLoS ONE 2010, 5, e8557. [CrossRef] [PubMed]

87. Hongo, I.; Oishi, K.; Morimoto, Y.; Hiramatsu, K.; Baba, T.; Ito, T. Phenol-soluble modulin enhances the human neutrophil lysis mediated by Panton-Valentine leukocidin. J. Infect. Dis. 2009, 200, 715-723. [CrossRef]

88. Malishev, R.; Tayeb-Fligelman, E.; David, S.; Meijler, M.M.; Landau, M.; Jelinek, R. Reciprocal interactions between membrane bilayers and S. aureus PSMalpha3 cross-alpha amyloid fibrils account for species-specific cytotoxicity. J. Mol. Biol. 2018, 430, 1431-1441. [CrossRef]

89. Cucarella, C.; Solano, C.; Valle, J.; Amorena, B.; Lasa, I.; Penadés, J.R. Bap, a Staphylococcus aureus surface protein involved in biofilm formation. J. Bacteriol. 2001, 183, 2888-2896. [CrossRef]

90. Lasa, I.; Penadés, J.R. Bap: A family of surface proteins involved in biofilm formation. Res. Microbiol. 2006, 157, 99-107. [CrossRef]

91. Sutra, L.; Poutrel, B. Virulence factors involved in the pathogenesis of bovine intramammary infections due to Staphylococcus aureus. J. Med. Microbiol. 1994, 40, 79-89. [CrossRef] [PubMed]

92. Van Gerven, N.; Klein, R.D.; Hultgren, S.J.; Remaut, H. Bacterial amyloid formation: Structural insights into curli biogensis. Trends Microbiol. 2015, 23, 693-706. [CrossRef] [PubMed]

93. Taglialegna, A.; Navarro, S.; Ventura, S.; Garnett, J.A.; Matthews, S.; Penades, J.R.; Lasa, I.; Valle, J. Staphylococcal bap proteins build amyloid scaffold biofilm matrices in response to environmental signals. PLoS Pathog. 2016, 12, e1005711. [CrossRef] [PubMed]

94. Matsuhisa, A.; Suzuki, N.; Noda, T.; Shiba, K. Inositol monophosphatase activity from the Escherichia coli suhB gene product. J. Bacteriol. 1995, 177, 200-205. [CrossRef] [PubMed]

95. Li, K.; Xu, C.; Jin, Y.; Sun, Z.; Liu, C.; Shi, J.; Chen, G.; Chen, R.; Jin, S.; Wu, W. SuhB is a regulator of multiple virulence genes and essential for pathogenesis of pseudomonas aeruginosa. mBio 2013, 4, e00419-13. [CrossRef]

96. Rosales-Reyes, R.; Saldías, M.S.; Aubert, D.F.; El-Halfawy, O.M.; Valvano, M.A. The suhB gene of Burkholderia cenocepacia is required for protein secretion, biofilm formation, motility and polymyxin B resistance. Microbiology 2012, 158, 2315-2324. [CrossRef]

97. Janczarek, M.; Skorupska, A. The Rhizobium leguminosarum bv. trifolii pssB gene product is an inositol monophosphatase that influences exopolysaccharide synthesis. Arch Microbiol. 2001, 175, 143-151. [CrossRef]

98. Dutta, A.; Bhattacharyya, S.; Kundu, A.; Dutta, D.; Das, A. Macroscopic amyloid fiber formation by staphylococcal biofilm associated SuhB protein. Biophys. Chem. 2016, 217, 32-41. [CrossRef]

99. Russell, M.W.; Mansson-Rahemtulla, B. Interaction between surface protein antigens of Streptococcus mutans and human salivary components. Oral Microbiol. Immunol. 1989, 4, 106-111. [CrossRef]

100. Purushotham, S.; Deivanayagam, C. The Calcium-induced conformation and glycosylation of scavenger-rich Cysteine repeat (SRCR) domains of glycoprotein 340 influence the high affinity interaction with antigen I/II homologs. J. Biol. Chem. 2014, 289, 21877-21887. [CrossRef]

101. Petersen, F.C.; Assev, S.; Van Der Mei, H.C.; Busscher, H.J.; Scheie, A.A. Functional variation of the antigen I/II surface protein in Streptococcus mutans and Streptococcus intermedius. Infect. Immun. 2002, 70, 249-256. [CrossRef] [PubMed]

102. Soell, M.; Hemmerlé, J.; Hannig, M.; Haïkel, Y.; Sano, H.; Selimovic, D. Molecular force probe measurement of antigen I/II-matrix protein interactions. Eur. J. Oral Sci. 2010, 118, 590-595. [CrossRef] [PubMed]

103. Busscher, H.J.; Van De Belt-Gritter, B.; Dijkstra, R.J.B.; Norde, W.; Van Der Mei, H.C. Streptococcus mutans and Streptococcus intermedius adhesion to fibronectin films are oppositely influenced by ionic strength. Langmuir 2008, 24, 10968-10973. [CrossRef] [PubMed] 
104. Kelemen, L.; Rizk, S.; Debreczeny, M.; Ogier, J.; Szalontai, B. Streptococcal antigen I/II binds to extracellular proteins through intermolecular beta-sheets. FEBS Lett. 2004, 566, 190-194. [CrossRef]

105. Nobbs, A.H.; Lamont, R.J.; Jenkinson, H.F. Streptococcus adherence and colonization. Microbiol. Mol. Biol. Rev. 2009, 73, 407-450. [CrossRef]

106. Brady, L.J.; Maddocks, S.E.; Larson, M.R.; Forsgren, N.; Persson, K.; Deivanayagam, C.; Jenkinson, H. The changing faces of Streptococcus antigen I/II polypeptide family adhesins. Mol. Microbiol. 2010, 77, 276-286. [CrossRef]

107. Kelly, C.; Evans, P.; Bergmeier, L.; Taylor, W.; Brady, L.; Lee, S.; Bleiweis, A.; Lehner, T. Sequencing and characterization of the $185 \mathrm{kDa}$ cell surface antigen of Streptococcus mutans. Arch. Oral Biol. 1990, 35, S33-S38. [CrossRef]

108. Larson, M.R.; Rajashankar, K.R.; Crowley, P.J.; Kelly, C.; Mitchell, T.J.; Brady, L.J.; Deivanayagam, C. Crystal structure of the C-terminal region of Streptococcus mutans Antigen I/II and characterization of salivary Agglutinin adherence domains. J. Biol. Chem. 2011, 286, 21657-21666. [CrossRef]

109. Troffer-Charlier, N.; Ogier, J.; Moras, D.; Cavarelli, J. Crystal Structure of the V-region of Streptococcus mutans antigen I/II at 2.4^ resolution suggests a sugar preformed binding site. J. Mol. Biol. 2002, 318, 179-188. [CrossRef]

110. Nylander, Å.; Forsgren, N.; Persson, K. Structure of the C-terminal domain of the surface antigen SpaP from the caries pathogenStreptococcus mutans. Acta Crystallogr. Sect. F Struct. Biol. Cryst. Commun. 2011, 67, 23-26. [CrossRef]

111. Heim, K.P.; Sullan, R.M.A.; Crowley, P.J.; El-Kirat-Chatel, S.; Beaussart, A.; Tang, W.; Besingi, R.; Dufrêne, Y.F.; Brady, L.J. Identification of a supramolecular functional architecture of Streptococcus mutans Adhesin P1 on the bacterial cell surface. J. Biol. Chem. 2015, 290, 9002-9019. [CrossRef]

112. Ayakawa, G.Y.; Boushell, L.W.; Crowley, P.J.; Erdos, G.W.; McArthur, W.P.; Bleiweis, A.S. Isolation and characterization of monoclonal antibodies specific for antigen P1, a major surface protein of mutans streptococci. Infect. Immun. 1987, 55, 2759-2767. [CrossRef] [PubMed]

113. Besingi, R.N.; Wenderska, I.B.; Senadheera, D.B.; Cvitkovitch, D.G.; Long, J.R.; Wen, Z.T.; Brady, L.J. Functional amyloids in Streptococcus mutans, their use as targets of biofilm inhibition and initial characterization of SMU_63c. Microbiology 2017, 163, 488-501. [CrossRef] [PubMed]

114. Russell, M.W.; Harrington, D.J.; Russell, R.R. Identity of Streptococcus mutans surface protein antigen III and wall-associated protein antigen A. Infect. Immun. 1995, 63, 733-735. [CrossRef] [PubMed]

115. Yoder, S.; Cao, C.-H.; Ugen, K.E.; Dao, M.L. High-level expression of a truncated wall-associated protein A from the dental cariogenic streptococcus mutans. DNA Cell Biol. 2000, 19, 401-408. [CrossRef] [PubMed]

116. Russell, R.R.B. Wall-associated protein antigens of Streptococcus mutans. J. Gen. Microbiol. 1979, 114, $109-115$. [CrossRef] [PubMed]

117. Han, T.K.; Zhang, C.; Dao, M.L. Identification and characterization of collagen-binding activity in Streptococcus mutans wall-associated protein: A possible implication in dental root caries and endocarditis. Biochem. Biophys. Res. Commun. 2006, 343, 787-792. [CrossRef]

118. Levesque, C.M.; Voronejskaia, E.; Huang, Y.C.C.; Mair, R.W.; Ellen, R.P.; Cvitkovitch, D.G. Involvement of sortase anchoring of cell wall proteins in biofilm formation by Streptococcus mutans. Infect. Immun. 2005, 73, 3773-3777. [CrossRef]

119. Disson, O.; Lecuit, M. Targeting of the central nervous system byListeria monocytogenes. Virulence 2012, 3, 213-221. [CrossRef]

120. Colagiorgi, A.; Bruini, I.; Di Ciccio, P.; Zanardi, E.; Ghidini, S.; Ianieri, A. Listeria monocytogenes Biofilms in the wonderland of food industry. Pathogens 2017, 6, 41. [CrossRef]

121. Jordan, S.J.; Perni, S.; Glenn, S.; Fernandes, I.; Barbosa, M.; Sol, M.; Tenreiro, R.; Chambel, L.; Barata, B.; Zilhao, I.; et al. Listeria monocytogenes biofilm-associated protein (BapL) may contribute to surface attachment of L. monocytogenes but is absent from many field isolates. Appl. Environ. Microbiol. 2008, 74, 5451-5456. [CrossRef] [PubMed]

122. Taglialegna, A.; Matilla-Cuenca, L.; Dorado-Morales, P.; Navarro, S.; Ventura, S.; Garnett, J.A.; Lasa, I.; Valle, J. The biofilm-associated surface protein Esp of Enterococcus faecalis forms amyloid-like fibers. NPJ Biofilms Microbiomes 2020, 6, 1-12. [CrossRef] [PubMed]

123. Nguyen, B.N.; Peterson, B.N.; Portnoy, D.A. Listeriolysin O: A phagosome-specific cytolysin revisited. Cell. Microbiol. 2019, 21, e12988. [CrossRef] [PubMed] 
124. Hotze, E.M.; Tweten, R.K. Membrane assembly of the cholesterol-dependent cytolysin pore complex. Biochim. Biophys. Acta Biomembr. 2012, 1818, 1028-1038. [CrossRef] [PubMed]

125. Bavdek, A.; Kostanjšek, R.; Antonini, V.; Lakey, J.H.; Serra, M.D.; Gilbert, R.J.C.; Anderluh, G. pH dependence of listeriolysin $\mathrm{O}$ aggregation and pore-forming ability. FEBS J. 2011, 279, 126-141. [CrossRef]

126. Osborne, S.E.; Brumell, J.H. Listeriolysin O: From bazooka to Swiss army knife. Philos. Trans. R. Soc. B Biol. Sci. 2017, 372, 20160222. [CrossRef]

127. Earl, A.M.; Losick, R.; Kolter, R. Ecology and genomics of Bacillus subtilis. Trends Microbiol. 2008, 16, 269-275. [CrossRef]

128. Branda, S.S.; Chu, F.; Kearns, D.B.; Losick, R.; Kolter, R. A major protein component of the Bacillus subtilis biofilm matrix. Mol. Microbiol. 2006, 59, 1229-1238. [CrossRef]

129. Stover, A.G.; Driks, A. Secretion, localization, and antibacterial activity of TasA, a Bacillus subtilis spore-associated protein. J. Bacteriol. 1999, 181, 1664-1672. [CrossRef]

130. Romero, D.; Vlamakis, H.; Losick, R.; Kolter, R. An accessory protein required for anchoring and assembly of amyloid fibres in B. subtilis biofilms. Mol. Microbiol. 2011, 80, 1155-1168. [CrossRef]

131. Diehl, A.; Roske, Y.; Ball, L.; Chowdhury, A.; Hiller, M.; Molière, N.; Kramer, R.; Stöppler, D.; Worth, C.L.; Schlegel, B.; et al. Structural changes of TasA in biofilm formation ofBacillus subtilis. Proc. Natl. Acad. Sci. USA 2018, 115, 3237-3242. [CrossRef] [PubMed]

132. El Mammeri, N.; Hierrezuelo, J.; Tolchard, J.; Cámara-Almirón, J.; Caro-Astorga, J.; Álvarez-Mena, A.; Dutour, A.; Berbon, M.; Shenoy, J.; Morvan, E.; et al. Molecular architecture of bacterial amyloids in Bacillus biofilms. FASEB J. 2019, 33, 12146-12163. [CrossRef] [PubMed]

133. Chai, L.; Romero, D.; Kayatekin, C.; Akabayov, B.; Vlamakis, H.; Losick, R.; Kolter, R. Isolation, characterization, and aggregation of a structured bacterial matrix precursor. J. Biol. Chem. 2013, 288, 17559-17568. [CrossRef] [PubMed]

134. Malishev, R.; Abbasi, R.; Jelinek, R.; Chai, L. Bacterial model membranes reshape fibrillation of a functional amyloid protein. Biochemistry 2018, 57, 5230-5238. [CrossRef] [PubMed]

135. Abbasi, R.; Mousa, R.; Dekel, N.; Amartely, H.; Danieli, T.; Lebendiker, M.; Levi-Kalisman, Y.; Shalev, D.E.; Metanis, N.; Chai, L. The bacterial extracellular matrix protein TapA is a two-domain partially disordered protein. ChemBioChem 2019, 20, 355-359. [CrossRef] [PubMed]

136. Romero, D.; Vlamakis, H.; Losick, R.; Kolter, R. Functional analysis of the accessory protein TapA in bacillus subtilis amyloid fiber assembly. J. Bacteriol. 2014, 196, 1505-1513. [CrossRef]

137. Earl, C.; Arnaouteli, S.; Bamford, N.C.; Porter, M.; Sukhodub, T.; Macphee, C.E.; Stanley-Wall, N.R. The majority of the matrix protein TapA is dispensable for Bacillus subtilis colony biofilm architecture. Mol. Microbiol. 2020, 1-14. [CrossRef]

138. Verma, N.; Srivastava, S.; Malik, R.; Yadav, J.K.; Goyal, P.; Pandey, J. Computational investigation for modeling the protein-protein interaction of TasA(28-261)-TapA(33-253): A decisive process in biofilm formation by Bacillus subtilis. J. Mol. Model. 2020, 26, 1-16. [CrossRef]

139. Caro-Astorga, J.; Perez-Garcia, A.; de Vicente, A.; Romero, D. A genomic region involved in the formation of adhesin fibers in Bacillus cereus biofilms. Front. Microbiol. 2015, 5, 745. [CrossRef]

140. Cámara-Almirón, J.; Navarro, Y.; Díaz-Martínez, L.; Magno-Pérez-Bryan, M.C.; Molina-Santiago, C.; Pearson, J.R.; De Vicente, A.; Perez-Garcia, A.; Romero, D.F. Dual functionality of the amyloid protein TasA in Bacillus physiology and fitness on the phylloplane. Nat. Commun. 2020, 11, 1-21. [CrossRef]

141. Steinberg, N.; Keren-Paz, A.; Hou, Q.; Doron, S.; Yanuka-Golub, K.; Olender, T.; Hadar, R.; Rosenberg, G.; Jain, R.; Cámara-Almirón, J.; et al. The extracellular matrix protein TasA is a developmental cue that maintains a motile subpopulation within Bacillus subtilis biofilms. Sci. Signal. 2020, 13, eaaw8905. [CrossRef] [PubMed]

142. Duanis-Assaf, D.; Duanis-Assaf, T.; Zeng, G.; Meyer, R.L.; Reches, M.; Steinberg, D.; Shemesh, M. Cell wall associated protein TasA provides an initial binding component to extracellular polysaccharides in dual-species biofilm. Sci. Rep. 2018, 8, 9350. [CrossRef] [PubMed]

143. Shafi, J.; Tian, H.; Ji, M. Bacillus species as versatile weapons for plant pathogens: A review. Biotechnol. Biotechnol. Equip. 2017, 31, 446-459. [CrossRef]

144. Pandin, C.; Le Coq, D.; Canette, A.; Aymerich, S.; Briandet, R. Should the biofilm mode of life be taken into consideration for microbial biocontrol agents? Microb. Biotechnol. 2017, 10, 719-734. [CrossRef]

145. Zeriouh, H.; de Vicente, A.; Perez-Garcia, A.; Romero, D. Surfactin triggers biofilm formation of Bacillus subtilis in melon phylloplane and contributes to the biocontrol activity. Environ. Microbiol. 2014, 16, 2196-2211. [CrossRef] 
146. Beauregard, P.B.; Chai, Y.; Vlamakis, H.; Losick, R.; Kolter, R. Bacillus subtilis biofilm induction by plant polysaccharides. Proc. Natl. Acad. Sci. USA 2013, 110, E1621-E1630. [CrossRef]

147. Chen, Y.; Yan, F.; Chai, Y.; Liu, H.; Kolter, R.; Losick, R.; Guo, J.H. Biocontrol of tomato wilt disease by Bacillus subtilis isolates from natural environments depends on conserved genes mediating biofilm formation. Environ. Microbiol. 2013, 15, 848-864. [CrossRef]

148. Pandin, C.; Darsonval, M.; Mayeur, C.; Le Coq, D.; Aymerich, S.; Briandet, R. Biofilm formation and synthesis of antimicrobial compounds by the biocontrol agent bacillus velezensis QST713 in an Agaricus bisporus compost micromodel. Appl. Environ. Microbiol. 2019, 85. [CrossRef]

149. Sarang, M.C.; Nerurkar, A.S. Amyloid protein produced by B. cereus CR4 possesses bioflocculant activity and has potential application in microalgae harvest. Biotechnol. Lett. 2020, 42, 79-91. [CrossRef]

150. Candela, T.; Fagerlund, A.; Buisson, C.; Gilois, N.; Kolstø, A.; Okstad, O.A.; Aymerich, S.; Nielsen-Leroux, C.; Lereclus, D.; Gohar, M. CalY is a major virulence factor and a biofilm matrix protein. Mol. Microbiol. 2019, 111, 1416-1429. [CrossRef]

151. Ren, B.; Zhang, Y.; Nussinov, R.; Liu, Y.; Zhang, D.; Gong, X.; Feng, Z.; Tang, J.; Chang, Y.; Zheng, J. Fundamentals of cross-seeding of amyloid proteins: An introduction. J. Mater. Chem. B 2019, 7, 7267-7282. [CrossRef]

152. Lim, K.H. Diverse misfolded conformational strains and cross-seeding of misfolded proteins implicated in neurodegenerative diseases. Front. Mol. Neurosci. 2019, 12, 158. [CrossRef] [PubMed]

153. Vasconcelos, B.; Stancu, I.-C.; Buist, A.; Bird, M.; Wang, P.; Vanoosthuyse, A.; Van Kolen, K.; Verheyen, A.; Kienlen-Campard, P.; Octave, J.-N.; et al. Heterotypic seeding of Tau fibrillization by pre-aggregated Abeta provides potent seeds for prion-like seeding and propagation of Tau-pathology in vivo. Acta Neuropathol. 2016, 131, 549-569. [CrossRef] [PubMed]

154. Waxman, E.A.; Giasson, B.I. Induction of intracellular Tau aggregation is promoted by Synuclein seeds and provides novel insights into the hyperphosphorylation of Tau. J. Neurosci. 2011, 31, 7604-7618. [CrossRef]

155. Jeter, C.; Matthysse, A.G. Characterization of the binding of diarrheagenic strains of E. coli to plant surfaces and the role of Curli in the interaction of the bacteria with Alfalfa Ssprouts. Mol. Plant Microbe Interact. 2005, 18, 1235-1242. [CrossRef] [PubMed]

156. Luna-Pineda, V.M.; Moreno-Fierros, L.; Cázares-Domínguez, V.; Ilhuicatzi-Alvarado, D.; Ochoa, S.A.; Cruz-Córdova, A.; Valencia-Mayoral, P.; Rodríguez-Leviz, A.; Xicohtencatl-Cortes, J. Curli of uropathogenic Escherichia coli enhance urinary tract colonization as a fitness factor. Front. Microbiol. 2019, 10, 2063. [CrossRef]

157. Macarisin, D.; Patel, J.; Bauchan, G.; Giron, J.A.; Sharma, V.K. Role of Curli and cellulose expression in adherence of Escherichia coli O157:H7 to spinach leaves. Foodborne Pathog. Dis. 2012, 9, 160-167. [CrossRef]

158. DeBenedictis, E.P.; Liu, J.; Keten, S. Adhesion mechanisms of Curli subunit CsgA to abiotic surfaces. Sci. Adv. 2016, 2, e1600998. [CrossRef]

159. Hammer, N.D.; Schmidt, J.C.; Chapman, M. The Curli nucleator protein, CsgB, contains an amyloidogenic domain that directs CsgA polymerization. Proc. Natl. Acad. Sci. USA 2007, 104, 12494-12499. [CrossRef]

160. Zhou, Y.; Smith, D.; Leong, B.J.; Brännström, K.; Almqvist, F.; Chapman, M.R. Promiscuous cross-seeding between bacterial amyloids promotes interspecies biofilms. J. Biol. Chem. 2012, 287, 35092-35103. [CrossRef]

161. Zaman, M.; Andreasen, M. Cross-talk between individual phenol soluble modulins in S. aureus biofilm formation. bioRxiv 2020. [CrossRef]

Publisher's Note: MDPI stays neutral with regard to jurisdictional claims in published maps and institutional affiliations.

(C) 2020 by the authors. Licensee MDPI, Basel, Switzerland. This article is an open access article distributed under the terms and conditions of the Creative Commons Attribution (CC BY) license (http://creativecommons.org/licenses/by/4.0/). 